\title{
The revelation of African culture in Long walk to freedom
}

\section{Munzhedzi James Mafela}

Long walk to freedom is the autobiography of Nelson Mandela. The author recounts his life, but at the same time deals with those experiences of his people and events he considers most significant. Writers of autobiographies are concerned primarily with themselves as subject matter. As Abrams writes: 'Autobiography is a biography written by the subject about himself'. ${ }^{1}$ This means that in an autobiography, the subject recounts his or her own history. The novelist Graham Greene says that an autobiography is only 'a sort of life'. Any such work is a true picture of what, at one moment in a life, the subject wished - or is impelled - to reveal of that life. ${ }^{2}$

Long walk to freedom recreates the drama of the experiences that helped shape Mandela's destiny. ${ }^{3}$ Throughout his life, Mandela fought for justice, freedom, goodness and love. The narrative is therefore a story about Mandela as well as the struggle of Africans in South Africa. The autobiography can thus be categorised as a historical or political narrative because it deals with matters affecting not only Mandela, but the nation as a whole. Shelston says that this type of narrative appeals to our curiosity about human personality, and to our interest in factual knowledge, in finding out 'what exactly happened!'4

As indicated above, the life of Mandela holds for us not only the political events that took place in the country, but also a record of the cultural life of his countrymen at the time, especially of Africans. One can therefore regard Mandela's life as representative of political, cultural and educational expression. Besides revealing the oppression he and his people experienced, the narrative reveals many cultural matters such as those affecting the institution of marriage, running a homestead, the life of a boy in a rural area, the role of women in the family and kinship relations.

The focus of this article is on kinship relations among Africans, as revealed in the narrative. The use of kinship relations will be highlighted to enhance an interpretation of some of the actions which would otherwise be difficult for readers to understand. This will bring more clarity to the storyline.

\section{Kinship relations}

Kinship is the organising principle of a society as it provides a good idea of the prevailing system of social organisation. The family is certainly fundamental in 
this regard. Kinship plays a basic part in the upbringing of the human individual, and has a universal place in human society. ${ }^{5}$ According to Grabun:

In all societies, people are divided into categories to perform certain tasks that have to be done and, at the same time, all these tasks contribute in their own ways to the running of the society that we may call social integration. ${ }^{6}$

Kinship relations differ from one culture to another. According to Van Warmelo, 'The context of the nomenclature of kinship varies considerably in different parts of the world. ${ }^{7}$ Hereunder, the difference of kinship relations between Western and African cultures is provided.

\begin{tabular}{|c|c|c|}
\hline Western Culture & English Meaning & African Culture \\
\hline \multirow[t]{2}{*}{ aunt } & sister of one's father & $\checkmark$ \\
\hline & sister of one's mother & $x$ (mother) \\
\hline \multirow[t]{2}{*}{ brother } & a man's male sibling & $\checkmark$ \\
\hline & a woman's male sibling & $\checkmark$ \\
\hline \multirow[t]{4}{*}{ cousin } & daughter or son of mother's brother & $\checkmark$ \\
\hline & daughter or son of father's sister & $\checkmark$ \\
\hline & daughter or son of mother's sister & $x$ (sister or brother) \\
\hline & daughter or son of father's brother & $x$ (sister or brother) \\
\hline \multirow[t]{4}{*}{ nephew } & son of a woman's sister & $x$ (son) \\
\hline & son of a man's brother & $x$ (son) \\
\hline & son of a woman's brother & $\checkmark$ \\
\hline & son of a man's sister & $\checkmark$ \\
\hline \multirow[t]{4}{*}{ niece } & daughter of a woman's sister & $\boldsymbol{x}$ (daughter) \\
\hline & daughter of a man's brother & $\boldsymbol{x}$ (daughter) \\
\hline & daughter of a woman's brother & $\checkmark$ \\
\hline & daughter of a man's sister & $\checkmark$ \\
\hline \multirow[t]{2}{*}{ sister } & a woman's female sibling & $\checkmark$ \\
\hline & a man's female sibling & $\checkmark$ \\
\hline \multirow[t]{2}{*}{ uncle } & brother of one's mother & $\checkmark$ \\
\hline & brother of one's father & $x$ (father) \\
\hline
\end{tabular}

Failure to grasp the differences in kinship relations between Europeans and Africans could make it difficult for the reader, both non-African and African, to understand the reasons behind some of the actions in the narrative. As Van Warmelo writes:

There exist certain differences between native and Europeans' ways of thought, and the social behaviour of the natives is guided by the standards of the society, which is moulded on a plan much different 
from ours. An understanding of social structure means insight into relationships. ${ }^{8}$

As indicated above, concepts such as brother, sister, uncle, aunt and cousin do not have entirely the same meaning as those found in English and other cultures. Those who may be called cousins may not necessarily be cousins according to African culture, as illustrated above.

In explaining kinship relations in African culture, Mandela writes:

In African culture, the sons and daughters of one's aunts and uncles are considered brothers and sisters, not cousins. We do not make the same distinctions among relations practised by Whites. We have no half-brothers or half-sisters. My mother's sister is my mother; my uncle's son is my brother; my brother's child is my son, daughter. ${ }^{9}$

The extract above has been added in the narration of events by the author to show that kinship relationship is the foundation of social life, and the basis of custom and law among the Africans. The author introduces the above to emphasise the unity that prevails among Africans. When people are closely related they will care for each other. Therefore, the chance of one's human rights being violated by another is limited. African culture does not preach individualism, but encourages living together as communities.

Kinship relations played an important role in shaping Mandela's political life. It was through following the traditions regarding kinship that Mandela came to understand the political situation in South Africa. For example, Kaizer Daliwonga Matanzima played an important role in Nelson Mandela's life, especially when they were at the University of Fort Hare together. Matanzima, who was senior to Mandela in age and royal status, looked after Mandela. Both Matanzima and Mandela are the descendants of King Ngubengcuka. They all belong to the Thembu Royal House. However, Matanzima is from the Great House and Mandela from the Ixhiba house. As a result, Mandela's rank in the royal house is subordinate to that of Matanzima. The function of Ixhiba is that of counsellor to the king. As Mandela comes from the Ixhiba house his function was to fulfil the role of counsellor to the royal house. At the same time, however, Mandela is Matanzima's father's younger brother. It is indicated in the narrative that Nelson Mandela is KD Matanzima's uncle, which is correct in English. According to African culture, however, Nelson Mandela is Matanzima's father even if he is younger than Matanzima, and should be respected as such; Matanzima is not Mandela's nephew as stated in the narrative, but Mandela's child because they all belong to the Thembu Royal House. This is illustrated by the extract below:

Fort Hare had only 50 students, and I already knew a dozen or so of them from Clarkebury and Healdtown. One of them who I was meeting for 
the first time was K.D. Matanzima. Though K.D. was my nephew according to tribal hierarchy, I was younger and far less senior to him. ${ }^{10}$

The mention of nephew may be confusing to the reader because, according to African culture, a nephew is a man's sister's son or a woman's brother's son. Matanzima is not Mandela's sister's son, but his brother's son. This could be confusing to both African and non-African readers. As far as the term nephew is concerned, in English it means the son of one's brother or sister. The meaning of nephew in African culture is restricted to the son of one's sister (if one is male) and one's brother (if one is female). The son of one's brother (if one is male) is one's son, and the son one's sister (if one is female) is one's son. According to African culture, a nephew is not regarded as one's immediate family because he belongs to another family. Therefore he has no power to influence life in his mother's family. Matanzima, on the other hand, is Mandela's immediate family member, and has the power to influence Mandela's life. That is why he was responsible for raising Mandela's political awareness and for looking after him while he was at university. Matanzima's rank in the royal family dictates that he should guide Mandela and look after him, although he is Mandela's son according to African culture. Matanzima was Mandela's mentor but later Mandela's political views advanced beyond those of Matanzima, to such an extent that he practised his role of advisor by advising both Matanzima and Sabata to keep out of homeland politics. This is revealed when the author says:

In many ways, Daliwonga still regarded me as his junior, both in terms of my rank in the Thembu hierarchy and in my own political development. While I was his junior in the former realm, I believed I had advanced beyond my one-time mentor in my political views. Whereas his concerns focused on his own tribe, I had become involved with those who thought in terms of the entire nation. I did not want to complicate the discussion by introducing grand political theories; I would rely on common sense and the facts of our history. Before we began, Daliwonga invited Mda, Letlaka and his brother George, to participate, but they demurred, preferring to listen to the two of us. 'Let the nephew and the uncle conduct the debate', Mda said as a sign of respect. ${ }^{11}$

Mandela did not agree with Matanzima's political views and this is why they planned to debate this issue. Although, according to African culture, Mandela is father to Matanzima, he is subordinate to Matanzima according to the Thembu hierarchy. The Thembu genealogy is explained by Mandela as follows:

Ngubengcuka, one of the greatest monarchs, who united the Thembu tribe, died in 1832. As was the custom, he had wives from the principal royal houses: the Great House, from which the heir is selected, the Right Hand House, and the Ixhiba, a minor house that is referred to by some 
as the Left Hand House. It was the task of the sons of the Ixhiba or Left Hand House to settle royal disputes. Mthikrakra, the eldest son of the Great House, succeeded Ngubengcuka and among his sons were Ngangelizwe and Matanzima. Sabata, who ruled the Thembu from 1954, was the grandson of Ngangelizwe a senior to Kaizer Daliwonga, better known as K.D. Matanzima, the former chief minister of the Transkei my nephew by law and custom - who was the descendant of Matanzima. The eldest son of the Ixhiba house was Simakade, whose younger brother was Mandela, my grandfather. ${ }^{12}$

The genealogy explained above is diagrammatically represented in Figure 1:

\section{THEMBU TRIBE}

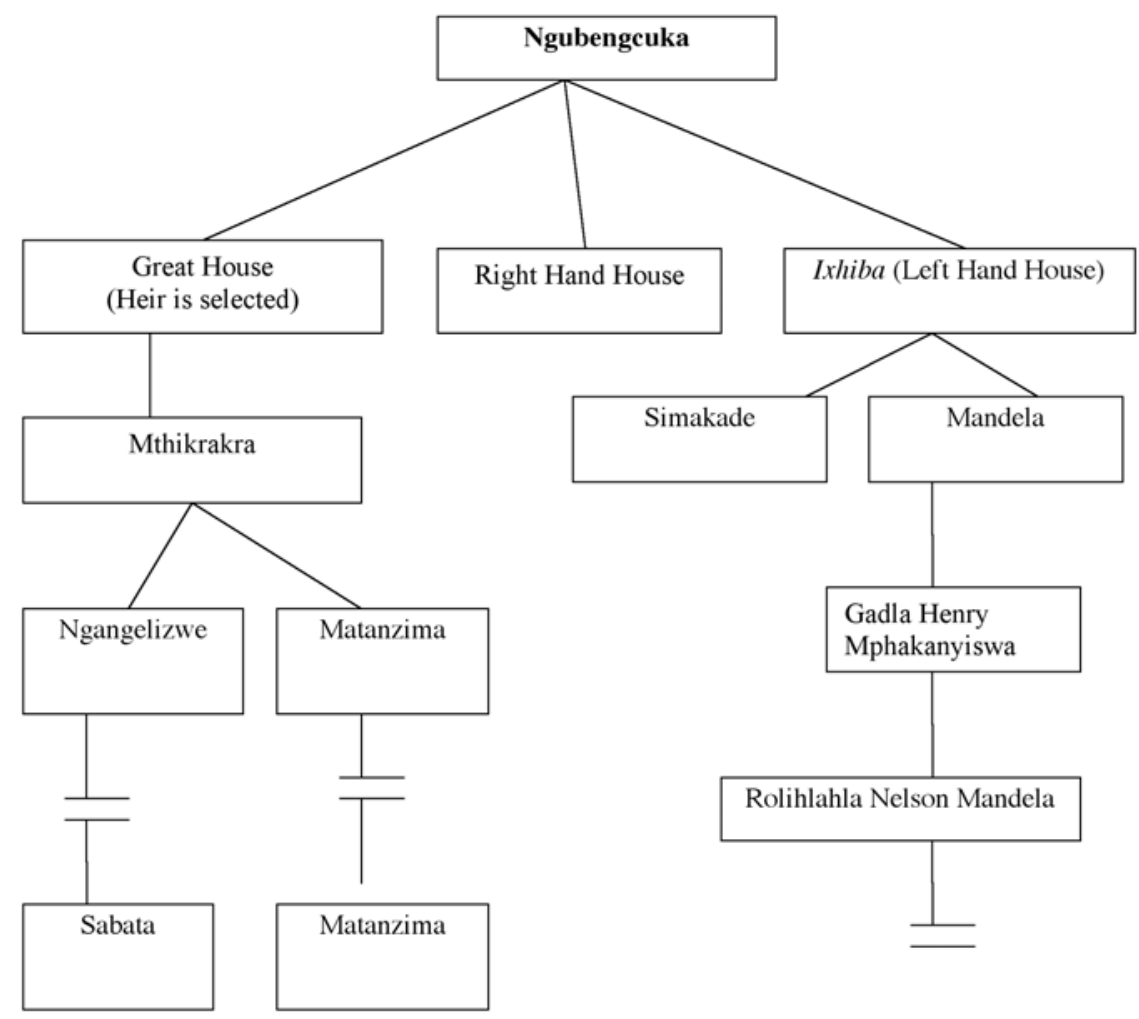

Figure 8.1: Genealogy of the Thembu tribe.

As indicated above, Matanzima is from the Great House, whereas Mandela is from the Ixhiba. It would therefore have been difficult for him to persuade Daliwonga to oppose the imposition of Bantu Authorities. However, it was within 
his rights to advise Daliwonga because he was counsellor to the royal house. Secondly, Matanzima and Mandela are nephew and uncle respectively. To take it at face value is confusing. According to African culture, Matanzima and Mandela are son and father respectively. In English, uncle denotes the brother of one's father or mother, and an aunt's husband. ${ }^{13}$ In African culture and custom, the use of uncle is restricted to the brother of one's mother. The brother of one's father is one's father. It would be expected in African culture that Matanzima be considered subordinate to Mandela; but because of the houses from which they come, Mandela is considered junior, and as such might not be heeded.

The above extract reveals the relationship between Nelson Mandela, KD Matanzima and King Sabata. These three are descendants of King Ngubengcuka, King of the Thembus. As indicated above, both King Sabata and Chief Matanzima are Mandela's children according to the Thembu hierarchy because he is brother to their fathers. However, Mandela is from the Ixhiba house, and does not qualify to be the King of the Thembus. Both Sabata and Matanzima are from the Great House, but Matanzima does not qualify to be the King of the Thembu people because the rightful person is Sabata. So, Mandela was not in line to succession of the Thembu throne, and he served as the counsellor to Thembu rulers. Mandela writes:

Although over the decades there have been many stories that I was in the line of succession to the Thembu throne, the simple genealogy I have just outlined exposes those tales as myth. Although I was a member of the royal household, I was not among the privileged few who were trained for the role. Instead, as a descendant of the Ixhiba house, I was groomed, like my father before me, to counsel the rulers of the tribe. ${ }^{14}$

It is not surprising that Mandela stayed at the Thembu Royal House under the guardianship of Jongintaba after his father's death. The main reason was to train him to counsel the rulers of the Thembu tribe. This is the function he tried to fulfil in advising King Sabata and Matanzima against accepting the imposition of Bantu Authorities. It was within his rights to counsel them and his behaviour was guided by African custom.

Another example of the confusion caused to readers by kinship terms involves the term cousin. Realising that they (Mandela and Justice) had failed to convince the regent (Jongintaba) not to force them to marry women chosen on their behalf, Mandela states:

In retrospect I realised that we did not exhaust all the options available to us. I could have attempted to discuss the matter with the regent through intermediaries and perhaps come to some settlement within the framework of our tribe and family. I could have appealed to the regent's 
cousin, Chief Zilindlovu, one of the most enlightened and influential chiefs at the court of Mqhekezweni. But I was young and impatient, and did not see any virtue in waiting. Escape seemed the only course. ${ }^{15}$

The abovementioned extract was uttered by the author after he was forced by the regent to take as his future wife a woman chosen on his behalf. Mandela did not accept the arrangement, and together with Justice, the regent's son who was also given a wife, he ran away. According to the Thembu law and custom, a father is responsible for choosing spouses for his sons. The regent had the right to arrange marriage for Nelson Mandela and Justice.

The main point under discussion here is the relationship between Zilindlovu and the regent, Jongintaba. According to African custom, Zilindlovu is not Jongintaba's cousin, but his brother, that is, either a younger or an elder brother to Jongintaba. This is why it is indicated that he is the most enlightened and influential chief at the court of Mqhekezweni. He could not have influenced the court of Mqhekezweni if he was just a cousin to Jongintaba. He could only exert his influence if he was an immediate family member. According to African culture, a cousin is the son or daughter of one's mother's brother or the son or daughter of one's father's sister. In English, children of one's father's brothers or sisters, or mother's sisters or brothers are all one's cousins. This is not the case in African culture; children of one's father's brothers or mother's sisters are one's brothers and sisters. Mönnig states that children of a father's brother are treated in much the same way as are a person's own brothers. ${ }^{16}$ The meaning of cousin in African culture is restricted to the children of one's father's sister and those of one's mother's brother. A cousin is therefore not considered as a member of one's immediate family, and he or she has limited influence in one's family's affairs. If Zilindlovu were Jongintaba's cousin he would have had no power to intervene in matters affecting the royal house. The role of a cousin is minimal compared to that of a brother.

The point here is that, since Zilindlovu is a member of the Thembu Royal House and has the power to intervene in matters affecting it, Mandela and Justice should have asked him to speak to the regent about the arranged marriages. As a brother to the regent, he may have succeeded in persuading the King to abandon the idea of choosing spouses for his son and Mandela, or he could have convinced the two young men to understand the position of the King. This may have made it unnecessary for Mandela and Justice to run away to Johannesburg to avoid marriage. Had the events followed this direction, perhaps the political situation in South Africa would have developed differently from what it has today. Going to Johannesburg deepened Mandela's political involvement. If he had stayed in the Transkei homeland, as suggested by KD Matanzima, his political views would have been restricted to that particular homeland. Johannesburg exposed him to the politics of the nation rather than simply the politics of a 
tribe. To summarise, one could claim that if Nelson Mandela had not been forced to marry a girl he did not love, his movement to Johannesburg would have been delayed or may never have happened at all. Hence he would not have experienced the hardships as narrated in the text, the hardships which shaped his political views.

The same applies to the relationship between Nelson Mandela and Justice. Justice and Mandela are revealed as cousins in the narrative. The truth is, Mandela and Justice are not cousins but brothers according to African culture and custom. That is why Jongintaba indicated that he would treat Mandela as any of his children. He regards him as his own son. Referring to this, Mandela says: "The regent and his wife No-England brought me up as if I were their own child. ${ }^{17}$

It is important to understand the social structure of the society in order to have an insight into the relationships. Knowledge of African culture may assist one in gaining such insight into relationships between Mandela and his people.

\section{Conclusion}

The actions of Mandela's close relatives, in particular Matanzima and the regent, Jongintaba, exerted great influence in determining his destiny. Besides the fact that Matanzima was Mandela's mentor and that Jongintaba exposed him to national affairs through forcing him to migrate to urban areas, both these men kept reminding him about his role in the Thembu Royal House, i.e. as counsellor to the Thembu rulers. This is what Mandela achieved in his lifetime; in addition to being counsellor of the Thembu rulers, Mandela saw himself as counsellor to the rulers of South Africa. He advised the Thembu rulers and resolved disputes in the Thembu Royal House. This role encouraged him to advise South African leaders and to resolve disputes in South Africa. In line with African culture, he saw all South Africans as members of one big family - brothers, sisters, nephews, cousins, nieces, and so on.

It is vital that the reader understands the differences between kinship relations in African and in European cultures. Without this insight the reader will not be able to make sense of or correctly interpret the events and conduct of characters in Long walk to freedom. Certain privileges are attached to certain kinship positions and these in turn inform people's actions and their prerogative to intervene in the lives of members of the close family.

\section{References}

Allen, RE (ed) 1990, The concise Oxford dictionary of current English, Clarendon Press, Oxford.

Abrams, MH 1981, A glossary of literary terms, Holt, Rinehart and Winston, New York. 
Grabun, N 1971, Readings in kinship and social structure, Harper \& Row Publishers, New York.

Hsu, FLK (ed) 1971, Kinship and culture, Aldine Publishing Company, Chicago.

Mandela, N 1994, Long walk to freedom: The autobiography of Nelson Mandela,: Little, Brown and Company, London.

McHenry, R (ed) 1992, The new encyclopaedia Britannica, Volume 23, Encyclopaedia Britannica, Inc, Chicago.

Mönnig, HO 1978, The Pedi, J.L. van Schaik, Pretoria.

Shelston, A 1977, Biography, Methuen \& Co. Ltd, London.

Van Warmelo, NJ 1931, Kinship terminology of the South African Bantu, Ethnological Publications, volume II, Government Printer, Pretoria.

\section{ENDNOTES}

\footnotetext{
1 Abrams 1981: 15.

2 McHenry 1992: 190.

3 Mandela 1994.

4 Shelston 1977: 3.

5 Hsu 1971: 5.

${ }^{6}$ Grabun 1971: 3.

${ }^{7}$ Van Warmelo 1931: 8.

${ }^{8}$ Van Warmelo 1931: 6.

9 Mandela 1994: 10.

10 Mandela 1994: 51-52.

11 Mandela 1994: 214-215.

12 Mandela 1994: 5.

13 Allen 1990: 1328.

14 Mandela 1994: 5.

15 Mandela 1994: 65.

16 Mönnig 1978: 237.

17 Mandela 1994: 21.
} 